\title{
Risk Management in an Electricity Transmission Project between Iceland and the UK
}

\author{
Daisuke Sasaki ${ }^{1}$, Mikiyasu Nakayama ${ }^{1}$ \\ ${ }^{1}$ Graduate School of Frontier Sciences, The University of Tokyo, Japan \\ Correspondence: Daisuke Sasaki, Graduate School of Frontier Sciences, The University of Tokyo, 5-1-5 Kashiwanoha, \\ Kashiwa-shi, Chiba 277-8563, Japan.
}

Received: November 23, 2015

Accepted: December 10, $2015 \quad$ Available online: December 28, 2015

doi:10.11114/ijsss.v4i2.1209

URL: http://dx.doi.org/10.11114/ijsss.v4i2.1209

\begin{abstract}
In recent years, energy is transmitted in the form of electricity in some parts of the world. Furthermore, all member states of the European Union (EU) have a legal obligation to ensure that $20 \%$ of their community energy consumption comes from renewable sources by 2020 . Therefore, there is a great demand for electricity derived from renewable sources while at the same time there are non-negligible risks in electricity transmission between nations. Addressing these risks is thus of great importance. Under such circumstances, the national power company in Iceland is investigating the possibility of installing a series of 800-1,200 MW high-voltage direct current (HVDC) submarine power cables of over a span of $1,000 \mathrm{~km}$ in an effort to deliver more than $5 \mathrm{TWh}$ of renewable electricity to the UK each year. In order to accelerate this project, the company must employ measures of risk prevention and/or mitigation. This study aims at revealing the potential risks of this project (called IceLink) using qualitative analysis. Thus far, there seems to be very few similar studies concerning the project, yet the results are significant from the viewpoint of risk management. Based on the results of interviews and a survey of the literature, we identify three major potential risks of the project: regulatory risk, political risk, and financial risk. In this regard, we classify risk in the same manner as a previous research. Subsequently, we suggest ways to manage these risks and as a result, we find that many of these measures can be introduced even under the present circumstances.
\end{abstract}

Keywords: risk management, renewable energy, electricity transmission, feed-in tariff, financing instrument, IceLink

\section{Introduction}

\subsection{Background}

Coal, petroleum, and natural gas have been traded as energy sources between nations since ancient times. In recent years, energy is transmitted in the form of electricity in some parts of the world. However, electricity transmission between nations does not necessarily occur even if there is a match between supply and demand. The reason for this is because of the risks inherent in electricity transmission projects, and these risks sometimes interrupt the projects. Additionally, previous research, e.g. Schmidt (2014), suggests that there are non-negligible risks present with low-carbon investments, and therefore reducing risk is of great importance.

According to Statistics Iceland (2015), Iceland is a country of $103,000 \mathrm{~km}^{2}$ and a population of 329,100 as of January 1 , 2015 . The proportion of hydro energy to total generation of electricity is $71 \%$, and that of geothermal energy is $29 \%$ as of 2013. Thus, it can be said that almost all electricity in Iceland is derived from renewable sources. Moreover, the existing capacity of hydro energy and geothermal energy is only $26 \%$ of the total potential power, while the capacity still to be developed is an additional 20\% (The IEA Geothermal Implementing Agreement, 2013).

At this moment, about $70 \%$ of electricity is consumed by aluminum smelters, the largest consumer in Iceland. However, domestic electricity prices in Iceland remain very low while electricity prices in nearby European nations are very high. More specifically, the average domestic wholesale electricity price in Iceland was just above 20 USD/MWh in 2014, while the wholesale electricity price to the UK was 80-140 USD/MWh at the same time (Askja Energy, 2015). Within this context, the plan to transmit electricity from Iceland to other European countries such as the UK at a higher price has been investigated for some time (Hammons, Lee, Chew, \& Chua, 1998). Furthermore, according to the European Union [EU] (2009), all member states of the EU now have a legal obligation to ensure that $20 \%$ of their community energy consumption comes from renewable sources by 2020 . Thus, there is a great demand for electricity derived from 
renewable sources.

Under the circumstances, Landsvirkjun, the national power company in Iceland, is investigating the possibility of installing 800-1,200 MW high-voltage direct current (HVDC) submarine cables of over 1,000 km that will deliver more than $5 \mathrm{TWh}$ of renewable electricity to the UK each year (Landsvirkjun, 2015a). The envisaged transmission route of IceLink is shown in Figure 1 (Nakayama, Sasaki, \& Ito, 2015).

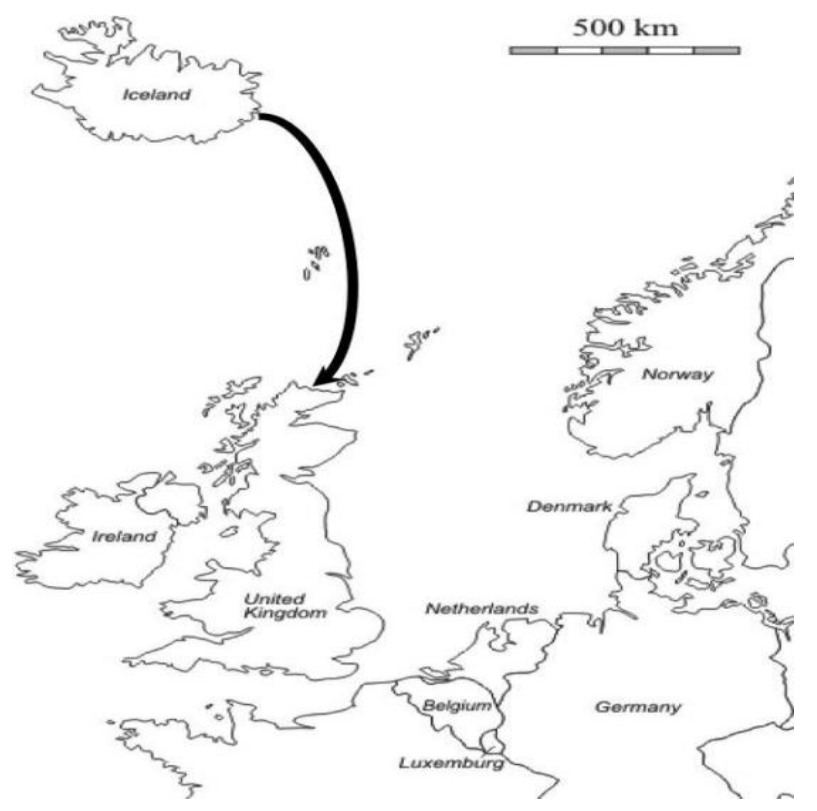

Figure 1. Planned trade of electricity from Iceland to UK in the IceLink project.

Source: Nakayama et al. (2015)

\subsection{Previous Research}

DESERTEC, the electricity transmission project between the Middle Eastern and North African (MENA) region and Europe, has already been investigated in other research. The schematic map of DESERTEC is shown in Figure 2. Incidentally, surplus desert power can supply $17 \%$ of the EU consumption (The DESERTEC Foundation, 2015).

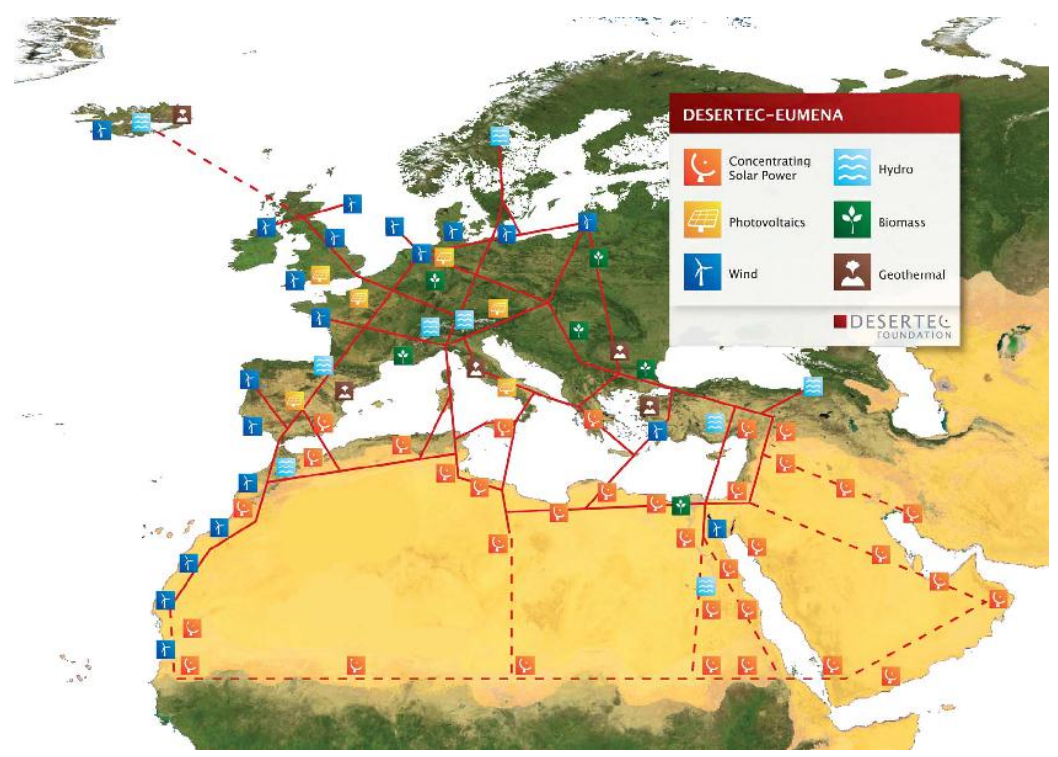

Figure 2. The schematic map of DESERTEC.

Source: The DESERTEC Foundation (2015) 
Backhaus, Gausling, and Hildebrand (2015) investigated the risks that stakeholders of DESERTEC are exposed to. As a result, they have determined that previous studies did not account for uncertainty in a comprehensive fashion, and they were likely to omit important risks. The real risks for this project are shown in Table 1.

Table 1. Risks reported for DESERTEC. Each number represents the occurrence of the risk in 222 online articles about DESERTEC that were published between 2007 and 2013.

\begin{tabular}{ccccccc}
\hline Organizational & $\begin{array}{c}\text { International } \\
\text { politics }\end{array}$ & $\begin{array}{c}\text { Country- } \\
\text { specific }\end{array}$ & Abandon & Revenue & Technical & External \\
\hline 143 & 67 & 35 & 24 & 16 & 11 & 9 \\
\hline
\end{tabular}

Source: Backhaus et al. (2015)

Thereby, it can be said that organizational risks (47\% of the total records) and risk due to international politics (22\%) are perceived to be more important than revenue risks (5\%) and technical risks (4\%). Backhaus et al. (2015) also pointed out that a project can be feasible when using the proper amount of risk mitigation, and these researchers introduced four possible courses of action (SERA) to deal with the risks of project: substitute risks by costs, eliminate risks, redistribute risk, and abandon the project (or shrink the project's size).

Komendantova, Patt, Barras, Battaglini (2012) examined risk as a barrier to investment in the case of concentrated solar power in North Africa, and these researchers divided the risks into nine types: regulatory, political, revenue, technical, force majeure, financial, construction, operating and environmental. Moreover, regulatory risks and political risks are much more significant than other risks in the projects that were examined. Incidentally, in this classification, complexity, and corruption of bureaucratic procedures as well as the instability of national regulations are included as a part of regulatory risks. Similarly, a low level of political stability in a country and the lack of support from local governments are included in political risks.

In addition, Khalfallah (2015) analyzed renewable energy trade via electricity corridors linking two regions of the Mediterranean basin and suggested that project participants would face a price-differential risk and volume risk. Therefore, a long-term contractual agreement could be the optimal framework for designing corridor projects that will bilaterally coordinate the necessary investments.

Similarly, Francés, Quemada , and González (2013) addressed the relationship between energy security/energy risk and renewable energy sources, applying their results to the EU Mediterranean Solar Plan. These researchers advocated that regulatory and institutional conditions must be on the same level in both the EU and North African countries in order to promote investment in renewable energy sources.

Incidentally, Van de Graaf and Sovacool (2014) examined four energy megaprojects, including DESERTEC, and this provides us with a good baseline reference. These researchers pointed out that all four projects suffered from a similar set of problems: too many stakeholders and stakeholder fragmentation, cost overruns and the risk of accidents and terrorist attacks, massive externalization of costs to third-party stakeholders, concentration of wealth and corruption, and inflated expectations and biased projections.

\subsection{Objectives and Research Questions}

This study aims to reveal the potential risks of a possible electricity transmission project between Iceland and the UK (i.e., IceLink) using a qualitative analysis. Thus far, there seems to be very few similar studies concerning this project, and it will be useful to obtain knowledge from the viewpoint of risk management. Incidentally, our research questions are as follows:

- What are the major potential risks of the electricity transmission project between Iceland and the UK that must be considered from the viewpoint of risk management?

- How can we avoid or mitigate these risks in order to expedite the project?

\section{Method}

This study adopts a method of interviews with relevant experts as well as a literature survey. Specifically, we held interviews in Reykjavik, Iceland from March 20-21, 2013, from March 12-14, 2014, and August 31, 2015 with the understanding that the Chatham House Rule applied. The names of the informants remain confidential. Based on the results of these interviews and the literature survey, we have identified several major potential risks to the project. In this regard, we classify these risks in the same manner as Komendantova et al. (2012), by dividing the risks into nine types: regulatory, political, revenue, technical, force majeure, financial, construction, operating and environmental. Finally, we make a suggestion to address the identified risks. 


\section{Results and Discussion}

\subsection{Identifying Major Potential Risks}

Through interviews and literature surveys, we have identified three major potential risks of an electricity transmission project between Iceland and the UK (i.e., IceLink) in the categories of regulatory risk, political risk, and financial risk. The following will include a detailed examination of each of these three risks.

3.1.1 Regulatory risk. Regulatory risk is related to the renewable energy support system in the UK, namely feed-in tariffs with contracts for differences (FiTs-CfDs), and we assume that these will be used in the project. The benefits of this system are that a fixed revenue can be guaranteed, and thus the project can be freed from revenue risk. In regards to this, Woodman and Mitchell (2011) also advocate that revenue risk such as volume risk or market risk can be removable using a system of FiTs. Thus, it can be said that the cash inflow of the project heavily depends on the system operated in the UK. At the present time there are some documents discussing the role of FiTs-CfDs in non-UK renewable electricity projects, such as a document from the Department of Energy \& Climate Change (2014). However, there are several uncertainties regarding the regulatory framework, and in this regard we identify regulatory risk as a critical risk in the project.

3.1.2 Political risk. Political risk means a risk of political intervention in Iceland, and there are two main contributors of this. The first contributor is the anxiety of large power consumers (i.e., aluminum smelters) fearing that the domestic wholesale power price in Iceland will rise in the future. According to Landsvirkjun (2015b), about $80 \%$ of electricity sales by Landsvirkjun in 2014 were made on long-term contracts to power intensive customers, mainly the aluminum smelters: Alcoa, Rio Tinto Alcan, Century Aluminum, Elkem, and Becromal, along with ferrosilicon plants and data centers. The large power consumers in Iceland are therefore immune in the short-term to price changes due to increases in wholesale electricity prices. However, it can be speculated that their long-term financial interests could lead to their opposition to the project as it would represent added competition for energy and potentially higher prices although their influence on the outcome is unknown. The other source of this risk is a sense of insecurity of Icelandic citizens, fearing that the price of power will raise simultaneously with the launch of IceLink. In other words, Icelandic citizens seem to be afraid that exporting electricity will result in soaring retail power prices as was the case in Sweden. In addition, many citizens are suspicious of their government due to the recent economic disaster. For these reasons, the political risk in Iceland is so important that particular caution will be required.

3.1.3 Financial risk. We can also identify the risk of a difficulty in raising sufficient funds. During the financial crisis of 2008, depositors of Landsbanki, one of the major Icelandic banks, at branches in the UK and the Netherlands lost access to their deposits. This case was eventually brought to the EFTA court by the EFTA Surveillance Authority (ESA) (Ministry for Foreign Affairs of Iceland, 2015). Therefore, the lingering impact of this incident, namely a certain credit crunch, seems to be making it difficult to raise long-term and stable funds for this project from overseas financiers. Meanwhile, there is a certain investment fund that has demonstrated its interest in the project (Atlantic Superconnection Corporation, 2015), however it is still uncertain whether it can come to terms with the expected rate of return of the project. Therefore, we conclude that financial risk is a real concern for the project.

\subsection{Addressing the Identified Risks}

Subsequent to identifying the risks inherent in this project, we suggest measures to address each of these risks.

3.2.1 Regulatory risk. According to Bürer and Wüstenhagen (2009), some investors are deeply skeptical about government involvement in this project in any form. A solution to this situation is that policy makers should make greater efforts to convince investors. Another view is that this project could be left to the markets. Apart from this, Backhaus et al. (2015) indicates that insurances offered by Export Credit Agencies (ECAs) are available for certain kinds of risks inherent in renewable energy projects. That is to say, it is the regulatory risk identified here can be substituted by costs in the form of insurances. In addition, there are private insurance companies that underwrite a certain degree of risk in Europe. Therefore, it is possible for these regulatory risks to be addressed to a certain extent even under the present circumstances of the project.

3.2.2 Political risk. Above all, it is essential that Landsvirkjun and the Government of Iceland provide thorough communication with the stakeholders. More specifically, they should convince large power consumers (i.e., aluminum smelters) that the diversification of their marketing channels resulting from new electricity transmission to the UK does not necessarily mean rise in the domestic wholesale price of power in the future. At the same time, both Landsvirkjun and the Government of Iceland should put Icelandic citizens at ease by committing to maintain the current retail power price. This is because they have broad discretion in the domestic power prices. Also, it may be effective to declare that there will be a subsidy for households using electric heating. Furthermore, they can explain that profit from the electricity transmission project will fund such a subsidy for domestic stakeholders. Moreover, secrecy about policies 
and effects on the public can possibly cause anxiety of citizens. Thus, project organizers should improve public disclosure and achieve accountability for all stakeholders.

3.2.3 Financial risk. Needless to say, it is the best to raise funds from Icelandic institutional investors in order to address the concerns of financial risk. In this regard, the Pension Fund for State Employees (LSR) is a good candidate, because pension funds are able to be invested in relatively long-term investments. At the end of 2014, the total assets of the LSR included about four billion USD at a rate of 130 Iceland Krona (ISK) per USD. Meanwhile, the amount of other investments, consisting of private equity and real estate, were 0.2 billion USD at the same exchange rate, equivalent to only about $5 \%$ of the total assets (LSR, 2014). Incidentally, the California Public Employees' Retirement System (CalPERS), one of the largest pension funds in the USA, allocated about $10 \%$ of their portfolio to private equity as of June 30, 2014 (CalPERS, 2014). Thus, there seem to be some potential investors in Iceland who can raise funds for the electricity transmission project that is now under consideration. Furthermore, new financing instruments are being recently advocated, and one of them is hybrid bond presented by Lee and Zhong (2015), whose comprehensive framework is shown in Figure 3.

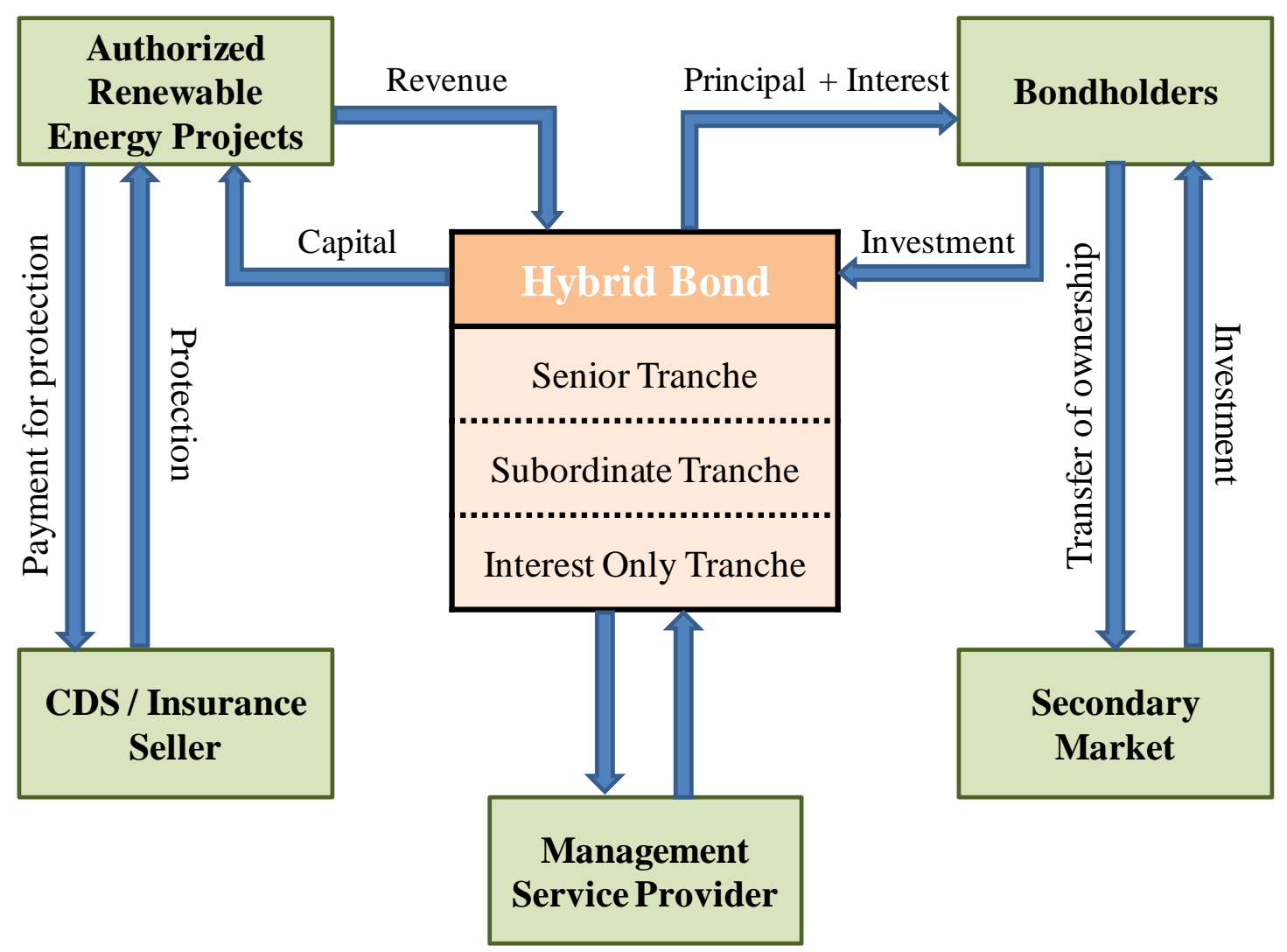

Figure 3. A comprehensive framework of the hybrid bond.

Source: Lee and Zhong (2015)

In addition, the hybrid bond is also effective for risk management, contributing to the optimization of risks. 


\subsection{Summary}

The summary of our discussions thus far is shown in Table 2.

Table 2. Summary of discussions

\begin{tabular}{|c|c|c|}
\hline Significant Potential Risks & Features & Measures \\
\hline Regulatory Risk & $\begin{array}{l}\text { There are several uncertainties } \\
\text { regarding the regulatory framework, } \\
\text { namely that the cash inflow of the } \\
\text { project heavily depends on the system } \\
\text { operated in the UK. }\end{array}$ & $\begin{array}{l}\text { Using insurances, this regulatory risk } \\
\text { can be substituted for increased costs. } \\
\text { There are private insurance companies } \\
\text { that underwrite a certain degree of risk } \\
\text { in Europe. }\end{array}$ \\
\hline Political Risk & $\begin{array}{l}\text { One of the two main factors is an } \\
\text { anxiety of large power consumers, i.e. } \\
\text { aluminium smelters; the other is a sense } \\
\text { of insecurity of Icelandic citizens. }\end{array}$ & $\begin{array}{l}\text { It is essential that Landsvirkjun and the } \\
\text { Government of Iceland make thorough } \\
\text { explanation of the stakeholders. It is } \\
\text { also important to explain that profit } \\
\text { from this project will be passed on to } \\
\text { domestic stakeholders in the form of } \\
\text { subsidy. }\end{array}$ \\
\hline Financial Risk & $\begin{array}{l}\text { With the after-effects of the } 2008 \\
\text { financial crisis, it seems very difficult to } \\
\text { raise long-term and stable funds from } \\
\text { overseas financiers. }\end{array}$ & $\begin{array}{l}\text { There seems to be some potential } \\
\text { investors in Iceland, such as the } \\
\text { Pension Fund for State Employees } \\
\text { (LSR). Furthermore, new financing } \\
\text { instruments such as hybrid bonds are } \\
\text { worth considering. }\end{array}$ \\
\hline
\end{tabular}

\section{Conclusions}

This study has identified three major potential risks associated with the IceLink project: regulatory risk, political risk, and financial risk. These results are similar to Komendantova et al. (2012) who advocate that regulatory risk and political risk are much more important than other risks, although its analytical targets are concentrated solar power projects in the North African region. Incidentally, it can be said that financial risk in Iceland is much more significant due to the after-effects of the 2008 financial crisis. Next, we have provided suggestions that address each major potential risk. Consequently, we find that many of the measures discussed above can be introduced even under the present circumstances. In order to accelerate the project, it is desirable to employ these measures from the viewpoint of risk management.

The future challenges of this study are two-fold: a) developing a new financial scheme based on the results of the risk analysis; b) implementing quantitative analyses such as a calculation of financial data. In regards to the former, we should keep in mind the basic principle of risk management - those who can control the risk most appropriately that should take that risk. In other words, the risk associated with the best financial scheme becomes optimal in most cases. Also, with respect to the latter, it is of great importance to consider future uncertainty from the viewpoint of risk management, because the life of the project is too long to foresee what will occur throughout the entire period. Specifically, some methods that deal with the uncertainty of the future may become applicable, including the real options theory. In any case, the financial scheme and the results of quantitative analyses should be self-consistent.

\section{Acknowledgements}

This study was supported by KAKENHI (25570003 and 15H02864), the 21st Century Culture and Academic Foundation, the University of Tokyo Graduate School of Frontier Sciences, and the Ministry of Economy, Trade, and Industry.

\section{References}

Askja Energy. (2015, September 28). Positive interest in IceLink. Retrieved October 11, 2015, from http://askjaenergy.org/2015/09/28/positiveinterestinicelink

Atlantic Superconnection Corporation. (2015). Atlantic superconnection corporation. Retrieved October 25, 2015, from http://www.atlanticsuperconnection.com

Backhaus, K., Gausling, P., \& Hildebrand, L. (2015). Comparing the incomparable: Lessons to be learned from models evaluating the feasibility of Desertec. Energy, 82, 905-913. http://dx.doi.org/10.1016/j.energy.2015.01.100

Bürer, M. J., \& Wüstenhagen, R. (2009). Which renewable energy policy is a venture capitalist's best friend? Empirical 
evidence from a survey of international cleantech investors. Energy Policy, 37(12), 4997-5006. http://dx.doi.org/10.1016/j.enpol.2009.06.071

California Public Employees' Retirement System (CalPERS). (2014). Comprehensive annual financial report: Fiscal Year Ended June 30, 2014. Sacramento, CA: California Public Employees' Retirement System (CalPERS).

Department of Energy \& Climate Change. (2014). Contract for difference for non-UK renewable electricity projects. London, United Kingdom: Department of Energy \& Climate Change.

DESERTEC Foundation. (2015). DESERTEC Flyer. Hamburg, Germany: DESERTEC Foundation.

European Union. (2009). Directive 2009/28/EC of the European Parliament and of the Council of 23 April 2009 on the promotion of the use of energy from renewable sources and amending and subsequently repealing Directives 2001/77/EC and 2003/30/EC. Retrieved from http://eur-lex.europa.eu/legal-content/EN/ALL/?uri=CELEX:32009L0028

Francés, G. E., Quemada, J. M. M., \& González, E. S. M. (2013). RES and risk: Renewable energy's contribution to energy security. A portfolio-based approach. Renewable and Sustainable Energy Reviews, 26, 549-559. http://dx.doi.org/10.1016/j.rser.2013.06.015

Hammons, T. J., Lee, K. O., Chew, K. H., \& Chua, T. C. (1998). Competitiveness of renewable energy from Iceland via the proposed Iceland /UK HVDC submarine cable link. Electric Machines \& Power Systems, 26(9), 917-933. http://dx.doi.org/10.1080/07313569808955867

IEA Geothermal Implementing Agreement. (2013). Iceland Country Report 2013. Reykjavik, Iceland: Orkustofnun.

Khalfallah, H. (2015). Connecting Mediterranean countries through electricity corridors: New institutional economic and regulatory analysis. Utilities Policy, 32, 45-54. http://dx.doi.org/10.1016/j.jup.2015.01.001

Komendantova, N., Patt, A., Barras, L., \& Battaglini, A. (2012). Perception of risks in renewable energy projects: The case of concentrated solar power in North Africa. Energy Policy, 40, 103-109. http://dx.doi.org/10.1016/j.enpol.2009.12.008

Landsvirkjun. (2015a). Submarine Cable to Europe. Retrieved October 11, 2015, from http://www.landsvirkjun.com/researchdevelopment/research/submarinecabletoeurope

Landsvirkjun. (2015b). Annual report 2014: Landsvirkjun's ongoing market drive. Retrieved October 25, 2015, from http://annualreport2014.landsvirkjun.com/increased-demand-and-new-opportunities/international-marketing-and-b usiness

Lee, C. W., \& Zhong, J. (2015). Financing and risk management of renewable energy projects with a hybrid bond. Renewable Energy, 75, 779-787. http://dx.doi.org/10.1016/j.renene.2014.10.052

Ministry for Foreign Affairs of Iceland. (2015). Icesave: Questions and answers. Retrieved October 26, 2015, from http://www.mfa.is/tasks/icesave/q-a

Nakayama, M., Sasaki, D., \& Ito, S. (2015). Domestic and diplomatic difficulties in planning for transboundary trading of electricity. Journal of Japan Society of Hydrology and Water Resources, 28, 72-83. http://dx.doi.org/10.3178/jjshwr.28.72 (Japanese)

Pension Fund for State Employees (LSR). (2014). Overview for LSR \& LH 2014. Reykjavik, Iceland: Pension Fund for State Employees (LSR).

Schmidt, T. S. (2014). Low-carbon investment risks and de-risking. Nature Climate Change, 4, 237-239. http://dx.doi.org/ 10.1038/nclimate2112

Statistics Iceland. (2015). Iceland in figures 2015. Reykjavik, Iceland: Statistics Iceland.

Van de Graaf, T., \& Sovacool, B. K. (2014). Thinking big: Politics, progress, and security in the management of Asian and European energy megaprojects. Energy Policy, 74, 16-27. http://dx.doi.org/10.1016/j.enpol.2014.06.027

Woodman, B., \& Mitchell, C. (2011). Learning from experience? The development of the Renewables Obligation in England and Wales 2002-2010. Energy Policy, 39(7), 3914-3921. http://dx.doi.org/10.1016/j.enpol.2011.03.074

\section{(c)) EY}

This work is licensed under a Creative Commons Attribution 3.0 License. 